\title{
The lichens of forest rocky communities of the hill Muroigora (Arkhangelsk Region, Northwest Russia)
}

\author{
Viktoria N. Tarasova ${ }^{1}$, Angella V. Sonina ${ }^{1}$, Vera I. Androsova ${ }^{1}$, Irina S. Stepanchikova ${ }^{2,3}$ \\ ${ }^{1}$ Department of Botany and Plant Physiology, Petrozavodsk State University, 33 Lenin St., 185910 Petrozavodsk, Russia. \\ E-mails: vika18@sampo.ru,vera.androsova28@gmail.com, angella_sonina@mail.ru \\ ${ }^{2}$ Department of Botany, St. Petersburg State University (SPbSU), 7-9 Universitetskaya emb., \\ 199034 St.-Petersburg, Russia. E-mail: stepa_ir@mail.ru \\ ${ }^{3}$ Laboratory of Lichenology and Bryology, Komarov Botanical Institute RAS, 2 Professor Popov St.,
}

197376 St. Petersburg, Russia

\begin{abstract}
The present study reports 188 species and 2 subspecies of lichens and allied fungi from forest rocky communities of the hill Muroigora situated in the Arkhangelsk part of the National park "Vodlozersky" (Arkhangelsk Region, NW Russia). Lepraria ecorticata is new to Russia, and 13 more species are new for the mainland area of the Arkhangelsk Region: Arthonia mediella, Arthonia vinosa, Bacidia igniarii, Bryoria vrangiana, Chaenothecopsis pusiola, Cladonia caespiticia, Lecidea plana, Lepraria borealis, Micarea misella, Pertusaria pustulata, Schaereria cinereorufa, Xanthoparmelia pulla and Xylographa trunciseda. Two lichen species, Bryoria fremontii and Lobaria pulmonaria, are in the Red Data Books of the Arkhangelsk Region and Russian Federation. A total of 89 species are reported as new for the Vodlozersky National Park.
\end{abstract}

Keywords: lichen list, old-growth forest, Vodlozersky National Park

\section{INTRODUCTION}

Rocky forest communities are typical for the territory of Fennoscandia. Rocky communities might represent key habitats for rare forest species (Nitare, 2000, Andersson et al., 2009). Lichens are a typical component of boreal forest communities, including rocky forests. They are sensitive to environmental disturbances and may be indicators of the degree of uniqueness of communities.

The Arkhangelsk Region is the largest territory of NW Russia. The lichen diversity of the Arkhangelsk Region is still poorly known compared with the other regions of Russia (see Tarasova et al., 2015).

The Vodlozersky National Park is the largest $(468,300 \mathrm{ha})$ protected area on the territory of NW Russia as well as in whole Europe. The park is located in two regions of Russia: in the Arkhangelsk region $(337,600 \mathrm{ha})$ and in the Republic of Karelia $(130,600$ ha). Within the Vodlozersky National Park one of the largest areas of European middle taiga covered with old-growth forests (about 600,000 ha) is located (Chervjakov, 2001). The park area includes the Lake Vodlozero and extensive basin of the Ileksa River which is the main tributary of the lake (mainly in the Arkhangelsk region).
The park is located on the eastern edge of the Fennoscandian Shield (Baltic Shield), on the border of the East European Plain. These two physiogeographic regions of Europe differ greatly in a range of conditions for growth of forest communities. Most of the territory of the park is covered by a plain mire landscape, with deep crystalline rocks. The northern part of the Park borders with the low-mountain ridge Windy Belt, which causes the presence here of a tectonic denudation of the landscape as individual rocky hills and ridges covered by forests. The study area is characterized by a heterogeneity of climatic and geomorphologic conditions. Therefore it arouses great scientific interest for the identification and analysis of biodiversity at different levels.

The history of the study of lichens of the Vodlozersky National Park started only after its establishing. In 1991 a Russian-Finnish lichenological expedition was organized to South Karelia including the Karelian part of the park (the source of the river Suchaja Vodla, Kuganavolok) with the following participants: M. P. Andreev, M. P. Zhurbenko, A. N. Titov (BIN RAS), T. Ahti, M. Kuusinen and O. Vitikainen (University of Helsinki, Finland). The results of this expedition 
were published partially for the whole biogeographical province Karelia transonegensis (Kton), without exact location (Fadeeva et al., 1997, 2007). For the vicinities of Pilmasozero and Kelkozero Lakes 88 lichen species were reported (Lapshin \& Osipov, 2001). The preliminary list of lichens of the Karelian part of the park included 155 species (Tarasova, 2000; Tarasova \& Stepanova, 2001). Several papers were published on lichen ecology (Gorshkov \& Tarasova, 2000; Gorshkov et al., 2002, Tarasova et al., 2005, 2012; Tarasova \& Kapitonihina, 2006 etc.) and on the distribution of protected species, Lobaria pulmonaria (Potasheva \& Kravchenko, 1995; Kravchenko \& Fadeeva, 2008) and Bryoria fremontii (Kravchenko, 2001). All the previous studies were carried out in the Karelian part of the park while no lichenological data about the Arkhangelsk part has been published, with the exception of one ecological paper where seven widespread terricolous lichens were mentioned (Tarasova \& Sonina, 2012). In general, the lichen diversity of the Vodlozersky National Park is still insufficiently known.
The present study focuses on lichen diversity of forest rocky communities. Moreover, the results of the present study make a contribution to the lists of lichens of the Vodlozersky National Park and the whole Arkhangelsk Region.

\section{MATERIALS AND METHODS}

\section{Study area}

The study area is located in the north-western part of the Arkhangelsk Region, $70 \mathrm{~km}$ south of the Onega Bay of the White Sea in the northeastern part of the National Park "Vodlozersky" (Fig. 1.). Muroigora (238 m a. s. 1., 633' $\mathrm{N}$ $36^{\circ} 61^{\prime} \mathrm{E}$ ) is an outcrop of solid crystalline rocks - diabase with boulders of different sizes (Kulikova et al., 2007). The hill which is about 0.6 $\mathrm{km}$ long and $0.3 \mathrm{~km}$ wide is covered by spruce, pine and mixed spruce-pine forests, often with an admixture of small-leaved deciduous trees.

On the top of Muroigora there is a depression covered by Quaternary sediments, and

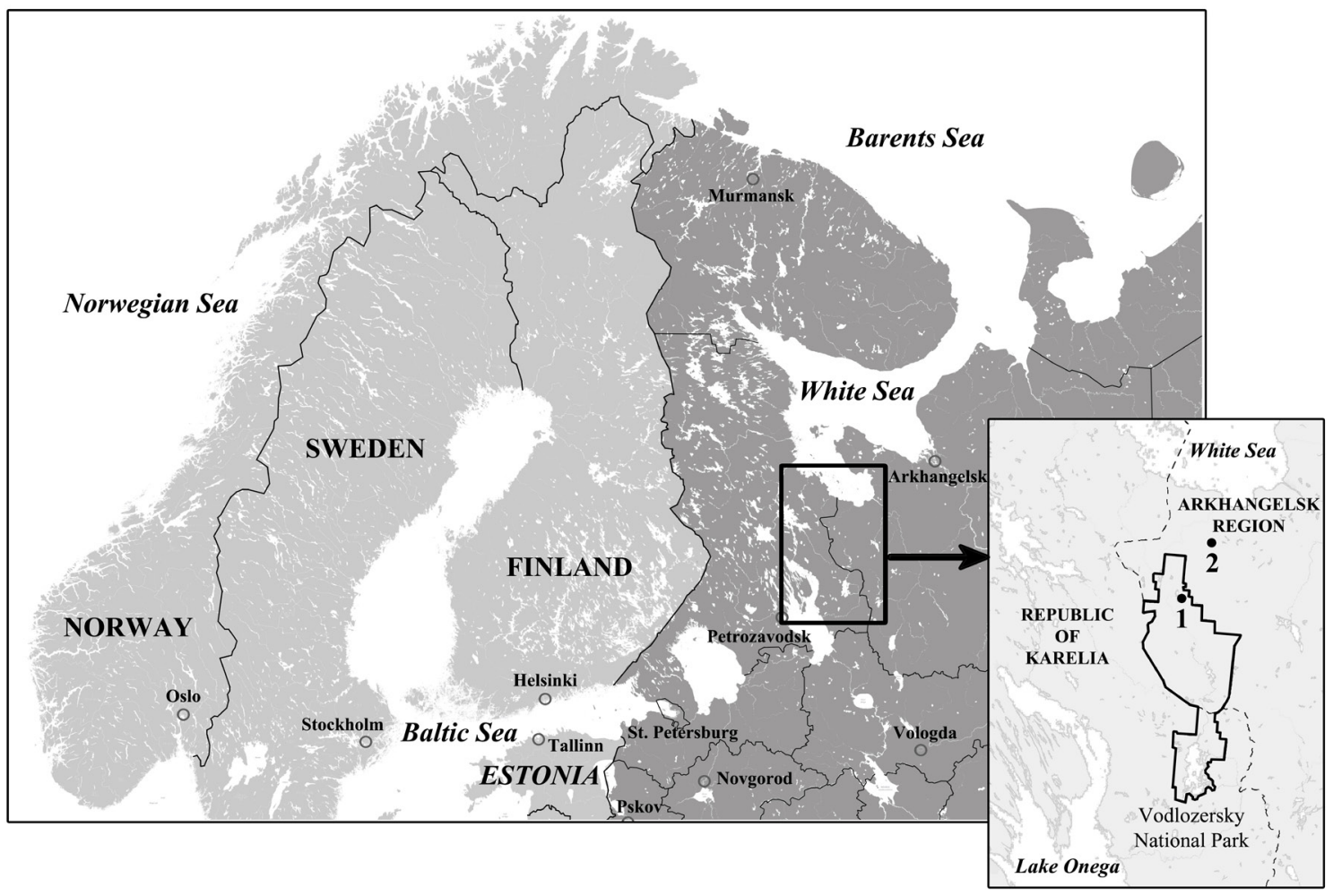

Fig. 1. The location of the study area (Arkhangelsk Region, NW Russia): thick line - border of the Vodlozersky National Park, 1 - hill Muroigora, 2 - hill Olovgora. 
spruce forest of Myrtillus-green mosses-type with Picea abies (L.) Karst. (85\%), Pinus sylvestris L. $(10 \%)$, and Betula pendula Roth. $(5 \%)$ in the tree stand. The maximum age of the tree stand varies from 250 (pine) to 104 (spruce, birch) years (Tarasova \& Sonina, 2012). The average projective cover of the shrub-grass layer is $80 \%$ with the dominance of Vaccinium myrtillus L. (share $75 \%$ ) and $V$. vitis-idaea L. (share $20 \%$ ). The ground vegetation consists mainly of mosses and lichens such as Pleurozium schreberi (Brid.) Mitt., Hylocomium splendens (Hedw.) Bruch et al., Dicranum spp., and Cladonia spp.

Below the mountain top, on the higher part of the slope, thickness of Quaternary sediments is reducing which results in a gradual replacement of spruce forests by rocky pine forests of Vaccinium vitis-idaea-lichens-green mossestype. The dominant species in the shrub layer are Vaccinium vitis-idaea (55\%), V. myrtillus $(15 \%)$ and Ledum palustre L. (5\%). The mosslichen layer is formed mainly by species of the genus Cladonia and mosses Pleurozium schreberi, Hylocomium splendens and Dicranum spp.

The middle part of the slope is covered by lichen-rich pine forests with sparse pine stands and a lichen-dominated ground layer (95\%). This part of the hill is characterized by numerous large boulders and stones of different sizes. Pine forests have originated after fire, which is typical in drained sites (Volkov, 2008). Within the rocky outcrops there are some pine trees older than 300 years with traces of five fires.

Towards the foot of the mountain slope the thickness of the Quaternary sediments increases and lichen-rich pine forest is replaced first by mixed spruce-pine forest, then by spruce forest of Vaccinium myrtillus-green mosses-type, and then by spruce forest of shrub-Sphagnum-type bordering with Sphagnum mire. At the foot of the slope, deciduous trees such as aspen (Populus tremula L.) and willow (Salix caprea L.) occur in the tree stand. The grass-shrub layer is well developed and has a total coverage of $60-70 \%$.

The age of the studied forests communities after the last fire is 172 years; normally, the fires are rare events for this type of communities. In fact, the known frequency of natural forest fires in the North-West Russia is 1-2 times per century for drained sites and 1-2 times in a millennium for wetlands (Gromtsev, 1990; Gorshkov, 1998). The age of the tree stand varies from 342 to 69 ; dominated by trees of $120-150$ years. In conclusion, the plant cover of Muroigora is a complex of different communities based mainly on the depth of the soil layer.

The climate of the study area is very close to the climate of the neighboring hill Olovgora described in our previous paper (Tarasova et al., 2015).

\section{Data collection}

The field work was carried out by the first three authors during two expeditions in June 2010 and 2011. A total of 7 sample plots of $20 \times 20 \mathrm{~m}$ were established along a transect on the northeastern slope of the hill Muroigora. A detailed geobotanical description of the rocky forest community was made for each sample plot including trees (height, age, basal area, crown density etc.) and the ground cover characteristics (shrub and herb cover, mosses and lichen cover) (Methods..., 2002). The epiphytic, saxicolous $(10 \times 20 \mathrm{~cm}$ plots $)$ and ground lichen communities $(1 \times 1 \mathrm{~m}$ plots $)$ were described in detail. The epiphytic lichen cover was studied at 80 trees on southern and northern expositions, at trunk base and at $130 \mathrm{~cm}$ above ground. The epilithic lichen cover was described on saxicolous substrates on different expositions. Total number of descriptions was 140 for terricolous lichen cover, 214 for saxicolous lichen cover, and 280 for epiphytic lichen cover. To estimate the total lichen species richness, species occurring on all types of substrates were examined: trunks and branches of trees, shrubs, deadwood, mosses, soil and primitive soil covering the surface of the stones, rotting wood and stumps, dead trees, and boulders. The total area of the investigated sample plots was 0.24 ha.

The collected material, a total of 1200 lichen specimens, was identified using a standard microscopic technique and spot tests. The specimens of the genus Cladonia and sterile crustose lichen species were identified by a standard technique of thin-layer chromatography (TLC) in the Laboratory of Experimental Botany of Petrozavodsk State University, Petrozavodsk, using solvent systems A, B and C (Orange et al., 2001). The nomenclature follows mainly Nordin et al. (2016), except for the Lepraria ecorticata (Kukwa, 2006).

The specimens are deposited in the herbarium of the Petrozavodsk State University (PZV). 


\section{List of study sites}

Arkhangelsk Region, Onega District, Vodlozersky National Park, hill Muroigora, north-eastern slope:

1) the central part of the plateau, spruce forest of Myrtillus-type (238-237 m a. s. 1., $\left.63^{\circ} 34^{\prime} 19^{\prime \prime} \mathrm{N}, 36^{\circ} 61^{\prime} 11^{\prime \prime} \mathrm{E}\right)$;

2) the edge of the plateau, top part of the slope, pine forest of Vaccinium myrtillus-type (235-233 m a. s. 1., 6334'20”N, 3661'22”E);

3 ) the higher part of the slope, pine forest of Vaccinium vitis-idea-type (229-226 $\mathrm{m}$ a. s. 1., 633'2' $\left.\mathrm{N}, 36^{\circ} 61^{\prime} 28^{\prime \prime} \mathrm{E}\right)$;

4) the central part of the slope, sparse pine forest of lichen-type (224-222 m a. s. 1., $\left.63^{\circ} 34^{\prime} 24^{\prime \prime} \mathrm{N}, 36^{\circ} 61^{\prime} 67^{\prime \prime} \mathrm{E}\right)$;

5) the lower part of the slope, spruce forests of Vaccinium myrtillus-type (219-218 $\mathrm{m}$ a.

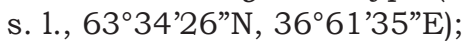

6) the initial part of slope foot, spruce forest of Vaccinium myrtillus-type (217-216 m a. s. 1., $\left.63^{\circ} 34^{\prime} 27^{\prime \prime} \mathrm{N}, 36^{\circ} 61^{\prime} 39^{\prime \prime} \mathrm{E}\right)$;

7) the foot of the slope, spruce forest of Equisetum-Sphagnum-type (214-213 m a. s. 1., $\left.63^{\circ} 34^{\prime} 28^{\prime \prime} \mathrm{N}, 36^{\circ} 61^{\prime} 43^{\prime \prime} \mathrm{E}\right)$.

\section{THE SPECIES}

Abbreviations and symbols: \# - lichenicolous fungi; + - non-lichenized fungi; * - the species is new for the mainland part of the Arkhangelsk Region; ! - the species is new to the Vodlozersky National Park.

Alectoria SARmentosa (Ach.) Ach. - on trunks and snags of Picea abies and Pinus sylvestris; 4, 5, 7 .

!ARCTOPARMELIA CENTRIFUGa (L.) Hale - on rocks and boulders; $1-5$.

!ARTHONIA DIDYMA Körb. - on trunks of Populus tremula; 7 .

*!ARTHONia MEDiella Nyl. - on trunks of Picea abies; 6.

*!ARTHONIA VINOSA Leight. - on trunks of Salix; 7.

*!Bacidia igniari (NyL.) Oxner - on trunks of Betula pubescens; 5.

!BAEOMYCES CARNEUS Flörke - on boulders and rocks; 6.

BAEOMYCES RUfus (Huds.) Rebent. - on rocks and soil; 1, 4, 6 .

!Biatora efflorescens (Hedl.) Räsänen - on trunks of Populus tremula; 7.
!Biatora OCELliformis (Nyl.) Arnold - on trunks of Betula pubescens, on standing deadwood of Pinus sylvestris; 2.

BRYORIA CAPILlaRIS (Ach.) Brodo \& D. Hawksw. - on branches and trunks of Picea abies and Pinus sylvestris, on trunks of Betula pubescens; 5-7.

BRYORIA FREMONTII (Tuck.) Brodo \& D. Hawksw. - on trunks of Picea abies; 6.

Bryoria furcellata (Fr.) Brodo \& D. Hawksw. on branches and trunks of Picea abies and Pinus sylvestris; 4-7.

BRYORIA FUSCESCENS (Gyeln.) Brodo \& D. Hawksw. - on branches and trunks of Betula pubescens, Picea abies and Pinus sylvestris; 1-7. Det. Leena Myllys, 2016.

BRYORIA IMPLEXA (Hoffm.) Brodo \& D. Hawksw. on branches and trunks of Picea abies and Pinus sylvestris; 4-7.BRYORIA NADVORNIKIANA (Gyeln.) Brodo \& D. Hawksw. - on trunks of Picea abies; $1-7$.

*!BRYoRIa VRANGIANA (Gyeln.) Brodo \& D. Hawksw. - on trunks of Picea abies and Pinus sylvestris; 4-7. Det. Leena Myllys, 2016.

Buellia Disciformis (Fr.) Mudd - on trunks of Populus tremula; 7.

!Buellia ERUBESCENS Arnold - on trunks of Populus tremula; 7.

Calicium Denigratum (Vain.) Tibell - on standing deadwood of Pinus sylvestris; 5 .

Calicium glaucellum Ach. - on trunks of Picea abies and Pinus sylvestris, on standing deadwood of Pinus sylvestris; 2-7.

CAlicium PARVUM Tibell - on trunks of Picea abies and Pinus sylvestris, on standing deadwood of Pinus sylvestris; 2-5.

CAlicium trabinellum (Ach.) Ach. - on standing deadwood of Pinus sylvestris; 2 .

CAlicium VIRIDE Pers. - on trunks of Picea abies and Pinus sylvestris, on standing deadwood of Pinus sylvestris; 1-4.

Caloplaca Cerina (Ehrh. ex Hedw.) Th. Fr. - on trunks of Salix sp.; 7.

!CANDELARIELla Xanthostigma (Ach.) Lettau - on standing deadwood of Pinus sylvestris; 3.

CETRARIA ISLANDICA (L.) Ach. - on soil, at the trunk base of Pinus sylvestris; 2-6.

Cetraria sepincola (Ehrh.) Ach. - on branches of Betula pubescens and Picea abies; 1-7.

Chaenotheca Brunneola (Ach.) Müll. Arg. - on trunks of Picea abies, on standing deadwood and snags of Pinus sylvestris; 1-7. 
Chaenotheca chrysocephala (Turner ex Ach.) Th. Fr. - on trunks of Picea abies, on standing deadwood of Pinus sylvestris; 1-7.

Chaenotheca ferruginea (Turner ex Sm.) Mig. - on trunks of Picea abies and Pinus sylvestris, on standing deadwood and snags of Pinus sylvestris; $1-7$.

Chaenotheca furfuracea (L.) Tibell - on roots of uprooted Picea abies; 1, 7.

!ChAENotheCA subroscida (Eitner) Zahlbr. - on trunks of Picea abies; 2, 3, 6.

Chaenotheca trichialis (Ach.) Hellb. - on trunks of Picea abies, Pinus sylvestris and Salix sp., on standing deadwood of Picea abies; 1, 6.

\#Chaenothecopsis consociata (Nádv.) A. F. W. Schmidt - on thalli of Chaenotheca chrysocephala on trunks of Picea abies; 1.

!\#CHAENOTHECOPSIS EPITHALLINA Tibell - on Chaenotheca trichialis on trunks of Salix sp.; 1, 7 .

!+CHAENOTHECOPSIS FENNICA (Laurila) Tibell - on standing deadwood of Pinus sylvestris; 3, 4.

!+CHAEnothecopsis NANA Tibell - on trunks of Picea abies; 6.

*!+Chaenothecopsis pusiola (Ach.) Vain. - on lignum of Pinus sylvestris; 3.

+ChaEnothecopsis savonica (Räsänen) Tibell - on lignum of Picea abies and Pinus sylvestris, on stumps; 3.

+Chaenothecopsis viridialba (Kremp.) A. F. W. Schmidt - on trunks of Picea abies; 2, 5.

!+CHAENOTHECOPSIS VIRIDIREAGENs (Nádv.) A. F. W. Schmid - on trunks of Picea abies, on standing deadwood of Pinus sylvestris; 6.

!CHRYSOTHRIX CANDELARIS (L.) J. R. Laundon - on lignum of standing deadwood of Pinus sylvestris; $3,4$.

!Cladonia albonigra Brodo \& Ahti - on soil; 3, 4. The specimens contain fumarprotocetraric acid complex.

Cladonia Amaurocraea (Flörke) Schaer. - on soil; $1-5$.

Cladonia arbuscula (Wallr.) Flot. - on soil; 1-5.

Cladonia BACILLIFORMIS (Nyl.) Glück - on trunks of Betula pubescens and Picea abies, on standing deadwood of Pinus sylvestris, on rotting wood; 4-7.

Cladonia Borealis S. Stenroos - on soil; 2-6. The specimen contains usnic and barbatic acids.

Cladonia botrytes (K. G. Hagen) Willd. - on soil, on rotting wood, at the trunk base of Picea abies; 6, 7 .

*!Cladonia Caespiticia (Pers.) Flörk - on base of trunk of Pinus sylvestris; 7.
Cladonia cenotea (Ach.) Schaer. - on soil, on rotting wood, on base of trunks of coniferous trees and Betula pubescens; 1-7.

Cladonia coccifera (L.) Willd. - on soil; 3, 4.

Cladonia coniocraea (Flörke) Spreng. - on soil, on base of trunks of coniferous trees and Betula pubescens; 1-7.

Cladonia CoRnuta (L.) Hoffm. - on soil, on standing deadwood of Betula pubescens, on rotting wood; $1-7$.

Cladonia CRISPATA (Ach.) Flot. - on soil, on rotting wood; $1-5$.

Cladonia deformis (L.) Hoffm. - on soil, on rotting wood; $3,4$.

Cladonia digitata (L.) Hoffm. - on soil, on base of trunks of Betula pubescens and Picea abies, on standing deadwood of Pinus sylvestris, on rotting wood; $1-7$.

Cladonia Fimbriata (L.) Fr. - on base of trunks of Picea abies and Pinus sylvestris, on rotting wood; 3-5.

Cladonia Furcata (Huds.) Schrad - on soil; 3, 4.

!Cladonia GRACILIS (L.) Willd. subsp. ELONGATA (Wulfen) Vain. - on soil; 3, 6.

CLADONIA GRACILIS subsp. GRACILIS - on soil; 2, 4, 5.

Cladonia GRACILIS subsp. TURBINATA (Ach.) Ahti - on soil; 2.

Cladonia Grayi G. Merr. ex Sandst. - on soil, on standing deadwood of Betula pubescens, on rotting wood; 1,2 . The specimens contain grayanic acid.

Cladonia macilenta Hoffm. - on soil; 3, 4.

!Cladonia merochlorophaEa Asahina - on soil, on base of trunks of Picea abies and Pinus sylvestris; 3, 4. The specimens contain merochlorophaeic and 4-O-methylcryptochlorophaeic acids, fumarprotocetraric acid complex.

Cladonia mitis Sandst. - on soil; 1-4.

!Cladonia Parasitica (Hoffm.) Hoffm. - on rotting wood; 3, 5, 7.

Cladonia Pleurota (Flörke) Schaer. - on soil; 1-4.

!Cladonia pyxidata (L.) Hoffm. - on soil, on base of trunks of Betula pubescens; 3-5. The specimens contain fumarprotocetraric acid complex.

Cladonia RANGiferina (L.) F. H. Wigg. - on soil, on rotting wood; $1-7$.

!Cladonia squamosa Hoffm. - on soil, on base of trunks of Picea abies; 1, 2.

Cladonia stellaris (Opiz) Pouzar \& Vězda - on soil; 3, 4.

!Cladonia stygia (Fr.) Ruoss - on soil; 1-4. 
Cladonia subulata (L.) Weber ex F. H. Wigg. - on soil, on base of trunks of Pinus sylvestris; 3,4 .

Cladonia sulphurina (Michx.) Fr. - on soil, on base of trunks of Betula pubescens, Picea abies and Pinus sylvestris, on rotting wood; $1-5$.

Cladonia uncialis (L.) F. H. Wigg. - on soil; 3, 4.

Cyphelium inguinans (Sm.) Trevis. - on trunk of Salix sp., on standing deadwood of Picea abies; 2.

!Cystocoleus eBeneus (Dillwyn) Thwaites - on rocks; $1-5$.

!Dibaeis BAEOMYces (L. f.) Rambold \& Hertel - on rocks; $1,4$.

!Diploschistes SCRUPOSUs (Schreb.) Norman - on rocks; $2,3,5$.

Evernia MESOMORPHA Nyl. - on trunks of Picea abies and Pinus sylvestris; 2.

!Fuscidea PUSILla Tønsberg - on trunks of Pinus sylvestris, Salix sp.; 1, 3. The specimens contain divaricatic acid.

Hertelidea Botryosa (Fr.) Printzen \& Kantvilas - on trunks of Picea abies; 1.

Hypocenomyce scAlaris (Ach.) M. Choisy - on trunks of Picea abies and Pinus sylvestris, on rotting wood; 5,6 .

HyPOGYMNIA PHYSODES (L.) Nyl. - on base of trunks of Betula pubescens, Picea abies and Pinus sylvestris, on standing deadwood of Picea abies, on rotting wood, on boulders; 1-7.

Hypogymnia tubulosa (Schaer.) Hav. - on trunks of Betula pubescens, Picea abies and Salix caprea, on standing deadwood of Picea $a b$ ies, on boulders; 1-7.

Hypogymnia vitTata (Ach.) Parrique - on trunks of Populus tremula, on boulders; 1, 3, 6.

ICMADOPHILA ERICETORUM (L.) Zahlbr. - on rotting wood; 1,3 . The specimens contain thamnolic and perlatolic acids.

Imshaugia Aleurites (Ach.) S. L. F. Mey. - on trunks of Picea abies and Pinus sylvestris, on standing deadwood of Pinus sylvestris; $1-7$.

!JAPEWIA SUBAURIFERA Muhr \& Tønsberg - on trunks of Betula pubescens, Picea abies and Salix sp., on standing deadwood of Pinus sylvestris, on rotting wood; 1, 2, 4-6.

!JAPEWIA TORNOËNSIS (Nyl.) Tønsberg - on trunks of Betula pubescens and Picea abies; 1, 2.

!LECANORA CHLAROTERA Nyl. - on trunks of Betula pubescens and Populus tremula; 1, 3.
LECANORA HYPOPTA (Ach.) Vain. - on trunks of Picea abies; 4.

!LECANORA PHAEOSTIGMA (Körb.) Almb. - on trunks of Picea abies; 1, 5.

LECANORA POPUlicola (DC.) Duby - on trunks of Populus tremula; 1.

LECANORA PULICARIS (Pers.) Ach. - on trunks of Betula pubescens; 3.

LECANORA symmicta (Ach.) Ach. - on trunks of Populus tremula; 1.

!LECIDEA ALBOFUSCESCENS Nyl. - on trunks of Picea abies; $1-6$.

!LECIDEA LEPRARIOIDES Tønsberg - on trunks of Picea abies; 6.

!LECIDEA NYLANDERI (Anzi) Th. Fr. - on trunks of Picea abies; 4.

*!LECIDEA PLANA (J. Lahm) Nyl. - on boulders and rocks; 6. Det. D. Himelbrant.

!Lecidea Pullata (Norman) Th. Fr. - on trunks of Betula pubescens and Picea abies; 3. The specimens contain sphaerophorin.

*!LEPRARIA BOREALIS Lohtander \& Tønsberg - on boulders and rocks; 1, 2, 4, 6. The specimens contain atranorin, roccellic/angardianic, jackinic/rangiformic acid.

*!LEPRARIA ECORTICATA (J. R. Laundon) Kukwa on boulders and rocks; 5,6 . The specimens contain zeorin, usnic acid. The species is new for Russia.

LEPRARIA INCANA (L.) Ach. - on trunks of Picea abies and Pinus sylvestris; 4, 5. The specimens contain divaricatic acid, atranorin and zeorin.

!LEPRARIA JACKII Tønsberg - on trunks and branches of Betula pubescens and Picea abies, on standing deadwood of Picea abies; $1-5$. The specimens contain atranorin, roccellic/angardianic, jackinic/rangiformic and norjackinic/norrangiformic acids.

!LEPRARIA NEGLECTA (Nyl.) Erichsen - on boulders and rocks; 1, 4, 6 . The specimens contain alectorialic acid.

!+LEPTORHAPHIS EPIDERMIDIS (Ach.) Th. Fr. - on trunks of Betula pubescens; 1-7.

LOBARIA PULMONARIA (L.) Hoffm. - on trunks of Salix sp.; 1, 2.

!LOBARIA SCROBICULATA (Scop.) DC. - on trunks of Salix sp.; 1, 2.

LOXOSPORA ELATINA (Ach.) A. Massal. - on trunks and branches of Betula pubescens, Picea abies and Pinus sylvestris; $1-7$. The specimens contain thamnolic and elatinic acids. 
!Melanelia hepatizon (Ach.) A. Thell - on boulders and rocks; 4.

!Melanelia stygia (L.) Essl. - on boulders and rocks; $1-4$.

Melanohalea olivacea (L.) O. Blanco et al. - on trunks of Betula pubescens, Picea abies and Salix sp.; 1-7.

!Melanohalea septentrionalis (Lynge) O. Blanco et al. - on trunks of Betula pubescens; 2, 6 .

!Micarea denigrata (Fr.) Hedl. - on lignum of fallen trees of Picea abies; 3.

Micarea melaena (Nyl.) Hedl. - on lignum of fallen trees and stumps, on trunks of Picea abies; 1, 5-7.

*!Micarea misella (Nyl.) Hedl. - on lignum of fallen trees of Picea abies, on standing deadwood of Pinus sylvestris, on rotting wood, on soil; $3,5,7$.

\#MicRocalicium Disseminatum (Ach.) Vain. - on thalli of calicioid lichens on trunks of Picea abies, on standing deadwood of Picea abies; $1,2,5,6$.

!MiriquidicA LeUCOPHAEA (Flörke ex Rabenh.) Hertel \& Rambold - on boulders and rocks; 1,6 .

!MonTANELIA PANNIFORMis (Nyl.) Divakar et al. - on soil, on boulders; 2.

!MonTANELIA SOREDiATA (Ach.) Divakar et al. - on boulders and rocks; 2, 4, 5 .

MycobilimBia CARNEOALBIDA (Müll. Arg.) S. Ekman \& Printzen - on trunks of Salix sp.; 1.

Mycoblastus AfFinis (Schaer.) T. Schauer - on trunks of Picea abies; 1, 6.

Mycoblastus sanguinarius (L.) Norman - on trunks of Betula pubescens, Picea abies, Pinus sylvestris and Populus tremula, on standing deadwood of Picea abies and Pinus sylvestris, on rocks and boulders; $1-7$. One sterile specimen with soralia was found (on snags of Picea abies; 7) which has been determined as Mycoblastus sanguinarius f. leprosus Nádv. The specimen contains atranorin, rhodocladonic acid and caperatic acid.

!+Mycocalicium subtile (Pers.) Szatala - on standing deadwood of Picea abies and Pinus sylvestris; 5,6 .

!+NAETROCYMBe Punctiformis (Pers.) R. C. Harris - on trunks of Salix sp.; 1.

!Nephroma arcticum (L.) Torss. - on soil; 1.

NePHROMA PARILE (Ach.) Ach - on trunks of Salix sp.; 1.

Nephroma Resupinatum (L.) Ach. - on trunks of Salix sp.; 1.
Ochrolechia ALBoflavescens (Wulfen) Zahlbr. on trunks and snags of Picea abies; 6, 7. The specimens contain variolaric, lichesterinic and protolichesterinic acids.

!OCHROLECHIA ARBOREA (Kreyer) Almb. - on trunks of Picea abies and Populus tremula; 1 . The specimens contain lichexanthone, gyrophoric and lecanoric acids.

!OCHROLECHIA FRIGIDA (Sw.) Lynge - on soil and boulders; 4-6. The specimens contain gyrophoric and lecanoric acids.

!OCHROLECHIA MAHLUENSIS Räsänen - on trunks and branches of Betula pubescens, Picea abies and Sorbus aucuparia, on standing deadwood of Betula pubescens and Picea abies; $1-7$. The specimens contain gyrophoric and lecanoric acids.

OCHROLECHIA MICROSTICTOIDES Räsänen - on trunks and snags of Picea abies, on standing deadwood of Picea abies; 1, 6. The specimens contain variolaric and lichesterinic acids and substances called "micristictoides-unknowns" (see Kukwa et al., 2011).

Ochrolechia pallescens (L.) A. Massal. - on branches of Picea abies; 5.

!PARMELIA OMPhalodes (L.) Ach. subsp. OMPHALODES - on boulders and rocks; $1-4$.

!Parmelia saXatilis (L.) Ach. - on boulders and rocks; $1-4$.

PARMELIA SULCATA Taylor - on trunks and branches of Betula pubescens, Picea abies, Populus tremula and Salix sp. on standing deadwood of Betula pubescens and Picea abies; 1-7.

PARMELIOPSIS AMBigua (Wulfen) Nyl. - on trunks and branches of Betula pubescens, Picea abies, Pinus sylvestris, Populus tremula and Salix sp., on rotting wood, on standing deadwood, on stumps; 1-7.

PARMELIOPSIS HYPEROPTA (Ach.) Vain. - on trunks of Picea abies and Pinus sylvestris, on standing deadwood of Picea abies and Pinus sylvestris; $1-7$.

Peltigera aphthosa (L.) Willd. - on soil; 2-3.

Peltigera leucophlebia (Nyl.) Gyeln. - on soil; 3.

Peltigera membranacea (Ach.) Nyl. - on soil; 3.

Peltigera neopolydactyla (Gyeln.) Gyeln. - on soil; 4, 6 .

!Peltigera occidentalis (Å. E. Dahl) Kristinsson - on soil; 3, 5, 6 .

PERTUSARIA AMARA (Ach.) Nyl. - on trunks of Betula pubescens and Picea abies, on standing deadwood of Picea abies; 1, 5, 7. 
!Pertusaria geminipara (Th. Fr.) C. Knight ex Brodo - on soil; 3-5.

*!Pertusaria PUStulata (Ach.) Duby - on trunks of Populus tremula; 7.

!Placynthiella icmalea (Ach.) Coppins \& P. James - on rotting wood, on standing deadwood of different trees; 1-7.

Platismatia glauca (L.) W. L. Culb. \& C. F. Culb. - on trunks and branches of Betula pubescens, Picea abies, and Pinus sylvestris, on standing deadwood, on boulders; 1-7.

!PoRPidia CINEREOATRA (Ach.) Hertel \& Knoph - on boulders and rocks; $1-6$.

PoRPIDIA CRUSTULATA (Ach.) Hertel \& Knoph - on boulders and rocks; $1-4$.

!PORPIDIA FLAVICUNDA (Ach.) Gowan - on boulders and rocks; $1,3$.

!PoRPIDIA TUBERCULOSA (Sm.) Hertel. \& Knoph - on boulders and rocks; $1,4$.

PSEUDEVERNIA FURFURACEA (L.) Zopf - on trunks and branches Betula pubescens, Picea abies, and Pinus sylvestris; 1, 2, 5, 6 .

!Psilolechia LuCIDA (Ach.) M. Choisy - on boulders; 4, 5.

RAMALINA THRAUSTA (Ach.) Nyl. - on trunks of Picea abies; 5.

!RHIZOCARPON BADIOATRUM (Flörke ex Spreng) Th. Fr. - on boulders and rocks; 1, 2, 4.

!RHIZOCARPON EUPETREUM (Nyl.) Arnold - on boulders and rocks; $1,2$.

!RHIZOCARPON GEOGRAPHICUM (L.) DC. - on boulders and rocks; 2, 3, 5 .

!RHIZOCARPON HOCHSTETTERI (Körb.) Vain. - on boulders and rocks; 2, 5 .

!+SAREA DifFormis (Fr.) Fr. - on resin of Picea abies; 2, 5.

!+SAREA RESINAe (Fr.) Kuntze - on resin of Picea abies; 2, 5.

*!Schaereria Cinereorufa (Schaer.) Th. Fr. - on boulders and rocks; 5 .

!Scoliciosporum CHLOROCOCCUM (Graewe ex Stenh.) Vězda - on standing deadwood of Populus tremula; 7.

!Stereocaulon grande (H. Magn.) H. Magn - on soil; 4.

Stereocaulon Paschale (L.) Hoffm. - on soil, on primary soil over boulders, on rotting wood; $1,2,6$.

!Stereocaulon saxatile H. Magn. - on soil, on primary soil over boulders; 3, 4 .

!THAMNOLIA VERMICULARIS (Sw.) Schaer. - on soil; 3,4 .
Trapeliopsis flexuosa (Fr.) Coppins \& P. James - on rotting wood; $3,4$.

TRAPELIOPSIS GRANUlosa (Hoffm.) Lumbsch - on soil; 4.

TUCKERMANOPSIS CHLOROPHYLLA (Willd.) Hale - on trunks and branches of Betula pubescens and Picea abies; 1-7.

UMBILICARIA DEUSTA (L.) Baumg. - on boulders and rocks; 2,5 .

!UMBILICARIA HYPERBOREA (Ach.) Hoffm. - on boulders and rocks; $1,2,5$.

!UMBILICARIA TORREFACTA (Lightf.) Schrad. - on boulders and rocks; 1, 3, 6 .

UsNeA DASOPOGA (Ach.) Nyl. - on trunks and branches of Betula pubescens, Picea abies and Pinus sylvestris, on standing deadwood; $1-7$.

USNEA HIRTA (L.) Weber ex F. H. Wigg. - on trunks and branches of Picea abies and Pinus sylvestris; $1-7$.

USNEA GLABRESCENS (Nyl. ex Vain.) Vain. ex Räsänen - on trunks of Picea abies and Salix sp.; 1.

!USNEA LAPPONICA Vain. - on branches of Picea abies; 7.

USNEA SUBFLORIDANA Stirt. - on trunks and branches Betula pubescens, Picea abies and Pinus sylvestris, on standing deadwood; 1-7.

!VARICELlaRia Lactea (L.) I. Schmitt \& Lumbsch - on boulders and rocks; 2.

!VARICELlaRia RHODOCARPA (Körb.) Th. Fr. - on trunks and branches of Betula pubescens, Picea abies and Pinus sylvestris, on standing deadwood; 1-7.

!Violella fucata (Stirt.) T. Sprib. - on trunks of Picea abies; 5 . The specimens contain atranorin and fumarprotocetraric acid.

VUlPICIDA PINASTRI (Scop.) J.-E. Mattsson \& M. $\mathrm{J}$. Lai - on trunks and branches of Betula pubescens, Picea abies and Pinus sylvestris, on standing deadwood, on rotting wood; 1-7.

*!XANTHOPARMElia PUlla (Ach.) O. Blanco et al. on boulders and rocks; 4.

!XYLOGRAPHA PALLENS (Nyl.) Malmgren - on lignum of coniferous trees; 3,5 .

*!Xylographa trunciseda (Th. Fr.) Minks ex Redinger - on lignum of Pinus sylvestris; 7.

XYlogRAPHA VITILIGo (Ach.) J. R. Laundon - on lignum of Picea abies; 6, 7. The specimens contain stictic acid complex.

Xylopsora Friesir (Ach.) Bendiksby \& Timdal on trunks and branches of Picea abies and Pinus sylvestris; 3-7. 


\section{DISCUSSION}

As a result of the study, 188 species and 2 subspecies of lichens and allied fungi belonging to 72 genera were found in the rocky forest communities of Muroigora. The most species-rich genera are Cladonia (31 species, 2 subspecies), Chaenothecopsis (8), Bryoria (7), Chaenotheca (6), Ochrolechia (6) and Lecanora (6). The other genera are represented by five species or fewer.

Fourteen lichen taxa are reported for the mainland area of the Arkhangelsk Region for the first time, one of them - Lepraria ecorticata - is new to Russia. The species Lobaria pulmonaria and Bryoria fremontii are included in the Red Data Books of Arkhangelsk Region (2008) and Russian Federation (Red..., 2008). Eleven species are regionally protected in the neighboring territory of Karelia (Red..., 2007): Arthonia vinosa, Bryoria fremontii, Bryoria nadvornikiana, Chaenotheca subroscida, Chaenothecopsis viridialba, Lecidea albofuscescens, Lobaria pulmonaria, Lobaria scrobiculata, Ramalina thrausta, Thamnolia vermicularis, and Varicellaria rhodocarpa while seven species are included in the Red Data Book of East Fennoscandia (1998): Bryoria nadvornikiana, Chaenotheca subroscida, Lobaria pulmonaria, Lobaria scrobiculata, Ramalina thrausta, Stereocaulon grande, and Varicellaria rhodocarpa.

A total of 109 species $(58 \%$ of the lichen flora) were found on bark of trees, and 30 of them also occurred on wood. Among the studied phorophytes the highest lichen species richness (64 species, 33\% of the lichen flora) was observed on trunks and branches of Picea abies. On bark of Pinus sylvestris 33 species (17\%) were recorded, on bark of Betula pubescens -26 species (13\%), on bark of Salix caprea- 17 species (9\%), on bark of Populus tremula- 7 species (4\%). The group of lignicolous lichens included 53 species ( $28 \%$ of the lichen flora), 14 of them were found only on lignum: Calicium denigratum, Calicium trabinellum, Candelariella xanthostigma, Chaenothecopsis fennica, Chaenothecopsis pusiola, Chaenothecopsis savonica, Chrysothrix candelaris, Cladonia parasitica, Icmadophila ericetorum, Micarea denigrata, Mycocalicium subtile, Placynthiella icmalea, Scoliciosporum chlorococcum, Trapeliopsis flexuosa, Xylographa pallens, Xylographa trunciseda, Xylographa vitiligo. Terricolous lichens included 52 taxa (26\%), of which 33 taxa were found only on soil. More than half
(33 taxa) of terricolous lichens belonged to the genus Cladonia. Thamnolia vermicularis was rather common on soil, as well as species of the genera Peltigera, Stereocaulon and Nephroma. Saxicolous lichens were represented by 36 species (18\% of the lichen flora), (30 of them were found on stones only). Most of the species developed epilithic thalli: Arctoparmelia centrifuga, Cystocoleus ebeneus, Psilolechia lucida, Lepraria borealis, Lepraria neglecta, Porpidia spp., Rhizocarpon spp. and Umbilicaria spp. The lichen species composition of Muroigora is typical for old-growth forests of the boreal zone.

The present list of lichens represents the first studied local lichen flora within the Arkhangelsk part of the Vodlozersky National Park. Altogether 89 species are new to the Park. Thus, at present time 250 lichen species are known for the Vodlozersky National Park.

The recent data on lichen diversity of this location in Arkhangelsk Region are known for rocky forest communities of hill Olovgora which is $25 \mathrm{~km}$ far from Muroigora (Fig 1.) (Tarasova et al., 2015). Both hills, Olovgora and Muroigora, are small, the total area of both together is less than one square kilometer but the lichen diversity of both areas is rather high (Olovgora 226 taxa, Muroigora - 190 taxa, common - 146 taxa). In general, high level of species richness is typical for forest rocky communities. Most recorded species of Muroigora are typical for lowland habitats of the middle taiga. Some arctic species the amount of are presented here by Nephroma arcticum and Thamnolia vermicularis. Nevertheless, the high heterogeneity of forest communities, as well as a great age of last disturbance lead to the fact that the number of species in Muroigora is quite high in spite of smaller examined square. The presence of lichen species - indicators of forest key habitats, such as Alectoria sarmentosa, Arthonia vinosa, Bryoria fremontii, Calicium denigratum, Chaenotheca subroscida, Chaenothecopsis fennica, Chaenothecopsis viridialba, Cladonia parasitica, Cyphelium inquinans, Hypogymnia vittata, Icmadophyla ericetorum, Lobaria pulmonaria, Lobaria scrobiculata, Microcalicium disseminatum, Nephroma arcticum, Nephroma parile, Nephroma resupinatum, Ramalina thrausta (Andersson et al., 2009) as well as a high species richness of the studied area can be accounted for variety of habitats and relatively long period of development without disturbances. 
The present study with high species number on relatively small area, together with high diversity of indicator species and ecological continuity of forest landscape underlines the high lichen diversity potential of rocky forest communities. Such type of communities is extremely vulnerable in general because of high frequency of fires, recreational use, cuttings and mining industry. These facts suggest the need of further inventories of lichen diversity in rocky forest communities.

\section{ACKNOWLEDGEMENTS}

We would like to express our gratitude to our colleagues Leena Myllys (University of Helsinki, Finland) for determination of Bryoria urangiana and Bryoria fuscescens, and Dmitry E. Himelbrant (St. Petersburg State University) for determination of Lecidea plana. The study was partially supported by the Ministry of Education and Science of the Russian Federation (project No 6.724.2014/k); work of I. Stepanchikova was partially supported by the Komarov Botanical Institute of the Russian Academy of Sciences (institutional research project No. 01201255601), the Russian Foundation for Basic Research (research grant 14-04-01411) and SaintPetersburg State University (research grant 1.37.151.2014). We are grateful to reviewers Juha Pykälä and Tiina Randlane for valuable corrections and recommendations, which have improved the quality of our work.

\section{REFERENCES}

Andersson, L., Alexeeva, N. \& Kuznetsova, E. (eds). 2009. Survey of biologically valuable forests in North-Western European Russia. Vol. 1. Method of survey and mapping. St.-Petersburg. 238 pp. Vol. 2. Identification manual of species to be used during survey at stand level. St. Petersburg. 258 pp. (In Russian).

Chervjakov, O. V. 2001. National Park "Vodlozersky" at the present stage of its development. National Park "Vodlozersky": the natural diversity and cultural heritage. Petrozavodsk: 9-15. (In Russian).

Fadeeva, M. A., Golubkova, N. S., Vitikainen, O. \& Ahti, T. 1997. Preliminary annotated list of lichens and lichenicolous fungi. Petrozavodsk. 100 pp. (In Russian).

Fadeeva, M. A., Golubkova, N. S., Vitikainen, O. \& Ahti, T. 2007. Conspectus of lichens and lichenicolous fungi of the Republic of Karelia. Petrozavodsk. 194 pp. (In Russian).
Gorshkov, V. V. 1998. The boreal forest communities: the formation and recovery of the stationary state of forest ecosystems after disturbances. In: Role of virgin terrestrial biota in the modern processes of global change: biotic regulation of the environment. Proceedings of the international conference. Petrozavodsk, pp. 138-190. (In Russian).

Gorshkov, V. V. \& Tarasova, V. N. 2000. The impact of forest fires on the epiphytic lichen cover of pine forests of southern Karelia. Plant resources 36(1): 18-29. (In Russian).

Gorshkov, V. V., Stepanova, V. I. \& Tarasova, V. N. 2002. Epiphytic lichen cover of branches of Picea abies (L.) Karst. (South Karelia). Plant resources 38(4): 1-14. (In Russian).

Gromtsev, A. N. 1990. Fire regimes in spontaneous forest landscape of north-west of the taiga and their transformation due to the anthropogenic factor. In: Problems of Forest Science and Forest Ecology. Proceedings of the conference. Minsk, pp. 96-98. (In Russian).

Kravchenko, A. V. 2001. About the protected lichen Bryoria fremontii in the National Park "Vodlozersky". In: National Park "Vodlozersky": the natural diversity and cultural heritage. Petrozavodsk, pp. 60-74. (In Russian).

Kravchenko, A. V. \& Fadeeva, M. A. 2008. Distribution and condition of Lobaria pulmonaria in the south-east of Fennoscandia. In: Lichens of boreal forests and Fourth Russian lichenological field school. Proceedings of the international conference. Syktyvkar, pp. 60-74. (In Russian).

Kukwa, M. 2006. Notes on taxonomy and distribution of the lichen species Lepraria ecorticata comb. nov. Mycotaxon 97: 63-66.

Kulikova, V. V., Kulikov, V. S. \& Bychkova, Y. V. 2007. Revising the volcano-plutonic system "Volcano Loach - Ruyga intrusion." Geology and Mineral Resources of Karelia. Proceedings of KRC RAS, Petrozavodsk 10: 69-81. (In Russian).

Lapshin, P. N. \& Osipov, M. N. 2001. Bryophytes and lichens in the district of Pilmasozero and Kolodozero Lakes. In: National Park "Vodlozersky": the natural diversity and cultural heritage. Petrozavodsk, pp. 168-182. (In Russian).

Methods of studying of forest communities. 2002. SaintPetersburg. Ed. Jarmishlo, V.T., Ljanguzova, I.V. 240 pp. (In Russian).

Nordin, A., Moberg, R., Tønsberg, T., Vitikainen, O., Dalsätt, Å., Myrdal, M., Snitting, D. \& Ekman, S. 2016. Santesson's Checklist of Fennoscandian Lichen-forming and Lichenicolous Fungi. http://130.238.83.220/santesson/ home.php (25 March 2016).

Orange, A., James, P. W. \& White, F. J. 2001. Microchemical methods for the identification of lichens. British Lichen Society, London. 101 pp.

Potasheva, M. A. \& Kravchenko, A. V. 1995. Protected lichen Lobaria pulmonaria in the National Park "Vodlozersky": distribution and habitats. In: $\mathrm{Na}$ - 
tional Park "Vodlozersky": the natural diversity and cultural heritage. Petrozavodsk, pp. 151-156. (In Russian).

Red Data Book of Arkhangelsk region. 2008. Arkhangelsk. 351 pp. (In Russian).

Red Data Book of East Fennoscandia. 1998. Helsinki. $351 \mathrm{pp}$.

Red Data Book of Karelian Republic. 2007. Petrozavodsk. 368 pp. (In Russian).

Red Data Book of Russian Federation (plants and fungi). 2008. Moscow. 885 pp. (In Russian).

Nitare, J. (ed.) 2000. Signalarter. Skogsstyrelsens forlag. $384 \mathrm{pp}$.

Tarasova, V. N. 2000. The epiphytic lichen pine forests protected areas of southern Karelia. Novitates Systematicae Plantarum Non Vascularum 34: 188-194. (In Russian).

Tarasova, V. N. 2014. Platismatia norvegica - a new lichen record from European Russia. Folia Cryptogamica Estonica 51: 131-134. https:/doi. org/10.12697/fce.2014.51.15

Tarasova, V. N., Androsova, V. I. \& Sonina, A. V. 2012. Lichens: physiology, ecology, lichenoindication. Petrozavodsk. 268 pp. (In Russian).

Tarasova, V. N. \& Kapitonikhina, O. V. 2006. Lichenbiota of dead pine trees in sphagnum pine forests of southern Karelia: species diversity and features of formation. In: Lichen Flora of Russia: state and perspectives of research. Proceedings of the international meeting on the 120th anniversary of the birth of V. P. Savich. St.-Petersburg, pp. 245-250. (In Russian).
Tarasova, V. N. \& Sonina, A. V. 2012. Formation of soil cover depending on occurrence depth of crystalline rocks in rocky forest communities of National Park "Vodlozersky" (Arkhangelsk region). Proceedings of the Samara Scientific Center of the Russian Academy of Sciences 1(5): 1379-1382. (In Russian, English summary).

Tarasova, V., Sonina, A., Androsova, V. \& Stepanchikova, I. 2015. The lichens of forest rocky communities of mountain Olovgora (Arkhangelsk Region, Northwest Russia). Folia Cryptogamica Estonica 52: 51-62. https:/doi.org/10.12697/ fce.2015.52.07

Tarasova, V. N. \& Stepanova, V. I. 2001. Preliminary list of lichens of the National Park "Vodlozersky". In: National Park "Vodlozersky": the natural diversity and cultural heritage. Petrozavodsk, pp. 183-192. (In Russian).

Tarasova, V. N., Stepanova, V I. \& Gorshkov, V. V. 2005. Role of species of the order Caliciales in the formation of epiphytic lichen cover of coniferous forests of southern Karelia. In: Fungi in natural and anthropogenic ecosystems. Proceedings of the international conference dedicated to the centenary of the beginning by professor A. S. Bondartsev his research activity at the $V$. L. Komarov Botanical Institute RAS, 24-28 April. St.-Petersburg, pp. 222-228. (In Russian).

Volkov, A. D. 2008. Types of forest of Karelia. Petrozavodsk. 180 pp. (In Russian). 
122 Folia Cryptog. Estonica 